\title{
ATIVidade TeStemunhal e TradiçÃo ORAL No EvangelHo SEgundo MARCOS
}

\author{
TESTIMONIAL ACTIVITY AND ORAL TRADITION \\ IN THE GOSPEL ACCORDING TO MARK
}

Sidney de Moraes Sanches *

\begin{abstract}
RESUMO
Esse Artigo examina a atividade testemunhal sobre Jesus de Nazaré que antecede e acompanha o período de formação das tradições orais nas primeiras congregações cristãs. Ele assume que o Evangelho segundo Marcos é uma transcrição e edição de testemunhos, onde seu Autor constrói uma vida de Jesus usando da voz de suas testemunhas. O Artigo descreve as noções fundamentais de testemunho e testemunha, trata brevemente do contexto testemunhal no Antigo (Primeiro) e Novo (Segundo) Testamento, para adentrar no tema dos testemunhos e das testemunhas no Evangelho segundo Marcos. Na parte principal, apresenta casos exemplares da atividade testemunhal no texto marcano. E, ao final, sugere critérios de: oralidade, narratividade, retoricidade, para a análise exegética dos testemunhos.
\end{abstract}

Palavras-chave: Evangelho segundo Marcos. Testemunhos. Testemunhas. Tradição oral. Exegese.

\begin{abstract}
This article examines the testimonial activity about Jesus of Nazareth that precedes and go along with the period of formation of the oral traditions at first Christian congregations. It assumes that Gospel of Mark is a transcription and edition of testimonies, where his Autor build a life of Jesus using the voice of his witnesses. The Article describes the fundamentals notions of testimony and witness, discuss briefly of the testimonial context at Old (First) and New (Second) Testament, to penetrates the theme of testimonies and witnesses at Gospel of Mark. At central part, presents exemplars cases of the testimonial activity at marcan text. And, at final, suggests criteria of: orality, narrativity and rhetoric, for the exegetical analysis of testimonies.
\end{abstract}

Keywords: Gospel of Mark. Testimonies. Witnesses. Oral tradition. Exegesis.

\section{INTRODUÇÃO}

Dunn (2013) entende que os estudos literários do Novo Testamento têm uma enorme dificuldade em lidar com a oralidade porque estão dirigidos para e pelo texto literário. Somos guiados por uma configuração-padrão que ele chama: paradigma literário, pelo qual:

[...] não estamos em condições apropriadas para avaliar como opera uma cultura não literária, uma cultura oral. E se queremos inserir-nos empaticamente em uma cultura oral, é essencial tomar consciência do nosso paradigma literário e fazer esforços deliberados para sair dele e livrar-nos de suas predisposições herdadas (DUNN, 2013, p. 99).

\footnotetext{
* Doutor em Teologia e pós-doutorando em Teologia pela Faculdade Jesuíta de Filosofia e Teologia (FAJE-Belo Horizonte), onde atua como professor e colaborador. Bolsista PNPD/CAPES. E-mail: sidney@sabercriativo.com.br
} 
Isso significa refletir sobre a natureza da tradição oral e o processo de transmissão oral em culturas construídas sob a oralidade, ou culturais orais, tais como as primeiras congregações cristãs. Estas recolheram os testemunhos de testemunhas: coletividades inteiras e indivíduos cristãos, que transmitiam, continuamente, sua experiência vivida com Jesus de Nazaré, formando tradições orais e escritas.

Perguntemos pela natureza da tradição oral. Comumente é descrita como o conteúdo de algo que chega até o presente transmitida através da boca e recebida pelos ouvidos. São crenças e costumes que se tornam importantes e autorizadas para uma comunidade e, por isso, são relembradas continuamente. Uma tradição oral deve ser diferenciada de uma memória individual, sendo vista como uma memória corporativa que molda a identidade de um grupo que, por isso mesmo, a relembra todo o tempo. Ela retém o seu caráter oral, mesmo que, em algum momento, seja reduzida à forma escrita (DUNN, 2003, p. 173). Sendo o Evangelho segundo Marcos a mais antiga fonte cristã que possuímos para o conhecimento de Jesus nazareno, que "tem sobrevivido intacto, que apareceu 40 anos após a morte de Jesus, e que contém tradições sobre Jesus que devem ter circulado na geração anterior àquela data" (DUNN, 2003, p. 146, tradução livre), devemos concluir que essas tradições orais foram nele reunidas, ainda que passando por diversas recensões do texto marcano primitivo (Ur-Markus) até a fixação do texto final, como temos no Novo Testamento. Isso é imaginável no contexto de uma cultura oral onde "muito do processo de formação de tradição incluiria variações orais das tradições usadas por Marcos, como também memórias orais daqueles que ouviram as leituras da versão de Marcos sobre a tradição de Jesus" (DUNN, 2003, p. 145-146, tradução nossa). Dunn sugere que, desde o início da atividade discipular de Jesus, foram criados grupos que contavam e recontavam suas obras e ensinos, gerando algum tipo de tradição embrionária formadora da identidade grupal (DUNN, 2003, p. 239-244).

Devemos dar um passo atrás e perguntar pelos testemunhos das testemunhas que antecederam à formação das tradições orais que culminaram na produção do evangelho por Marcos. Bauckham chegou muito perto, em sua obra: Jesus e as Testemunhas Oculares (BAUCKHAM, 2011), quando declara que: “O Jesus que os Evangelhos descrevem é Jesus como essas testemunhas oculares o descreveram, o Jesus do testemunho" (BAUCKHAM, 2011, p. 597). Sua pesquisa reorienta os estudos da tradição oral para a abordagem das testemunhas oculares como os filtros preservadores e mediadores da tradição e memória 
oral sobre Jesus de Nazaré, “não somente em relação a episódios particulares ou a ditos específicos de Jesus, mas com respeito a todo o curso da história de Jesus" (BAUCKHAM, 2011, p. 151). Bauckham dá, como exemplo, o Evangelho segundo Marcos. Neste, a história de Jesus é contada a partir da memória individual de Pedro que, por sua vez, define a memória coletiva das primeiras congregações cristãs.

Dando um passo ainda mais atrás, verificamos que a narrativa marcana não evoluiu a partir de tradições orais e escritas de uma memória cristã corporativa, muito menos de uma única testemunha ocular, no caso, Pedro, mas por meio de um sem-número de testemunhas individuais, em sua maioria anônimas, que levaram a fama de Jesus a todo lugar, sem o qual a própria existência e significado histórico de Jesus de Nazaré não faria o menor sentido. Os testemunhos formaram a memória individual e popular, não oficial nem autorizada, de seguidores e não-seguidores de Jesus de Nazaré.

A origem desses testemunhos era o território da Galileia (Mc 1, 9-14; 39; Mc 7, 30; Mc 15, 41) ${ }^{1}$, suas cercanias (Mc 1, 28), e regiões circunvizinhas: Judeia, Jerusalém, Idumeia, dalém do Jordão e dos arredores de Tiro e de Sidon (Mc 3, 8), lugares preferidos por Jesus para suas andanças (Mc 7, 24-31), que alertaram as autoridades políticas regionais (Mc 6, 14-29). Após a ressurreição, ele retornou para a Galileia, e seus discípulos se reuniram com ele na mesma região onde tudo começou, para dar início a congregações de seguidores (Mc 14, 28; Mc 16, 7). Aparecendo em cenários diferentes na narrativa, os testemunhos vão sustentando um retrato de Jesus, ao mesmo tempo em que vão ligando suas ações ao desenlace da narrativa: a ressurreição acerca da qual as mulheres são as primeiras testemunhas.

Inúmeras vezes o texto marcano conta que a fama de Jesus de Nazaré se espalhava graças aos testemunhos de sua pregação e milagres (Mc 1, 28-45; Mc 2, 12; Mc 5, 18-20; Mc 7, 36-37; Mc 8, 27-28; Mc 9, 38-40). Os testemunhos eram uma resposta à sua iniciativa de ir, propositalmente, até as pessoas a fim de evangelizá-las, anunciando a chegada do Reinado de Deus (Mc 1, 14-15). Esse era o entendimento que possuía de sua missão ou propósito na vida (Mc 1, 38-39). As pessoas respondiam positivamente ao empenho com que ele fazia isso: coletivamente (Mc 1, 32-33; 37; Mc 2, 1-2; 13; Mc 3; Mc 7, 8-20; Mc 4, 1; Mc 5, 21; Mc 6, 34; Mc 6, 53-56; Mc 9, 14-15; Mc 10, 1; Mc 11, 8-10; 18; Mc 12, 12-37; Mc 14, 2), e individualmente (Mc 1, 40; Mc 2, 3; Mc 3, 1; Mc 5, 2; 22-27; Mc 7, 24-32; Mc 8, 22; Mc 9, 17;

\footnotetext{
${ }^{1}$ Todas as citações de livros bíblicos têm como referência a BÍBLIA SAGRADA (2008).
} 
Mc 10, 17-46). Os testemunhos também explicam a razão da reação de seus adversários (Mc 3; Mc 6, 21-22; Mc 11, 18; Mc 12, 12; Mc 14, 1). O próprio texto marcano se apresenta como um testemunho: “de Jesus Cristo, Filho de Deus” (Mc 1, 1).

Por fim, indaguemos pelo trabalho editorial de Marcos que, como tal, foi um memorialista que através do seu texto construiu uma vida (bios) de Jesus dando voz a seus seguidores (DUNN, 2003, p. 184-185; AUNE, 1988, p. 121-125). Sua obra, então, contribuiu para: conhecimento da memória de Jesus entre seus seguidores, da forma como era guardada e celebrada, de modo a mantê-lo vivo e próximo, e para que outros e outras viessem a crer e celebrar juntamente com eles; ordenar a cristologia subjacente aos testemunhos a partir da imagem messiânica de Jesus de Nazaré; mostrar o ambiente conflituoso no qual os testemunhos eram dados, chamando à conversão e, senão, afirmando a condenação dos ouvintes impenitentes.

\section{SOBRE O TESTEMUNHO E A TESTEMUNHA}

Testemunhar é relembrar e isso é evidente na etimologia do vocábulo testemunha, que traduz o termo grego martys, procedente da raiz indo-europeia smer: "ter em mente", "lembrar". O testemunho é manuseado em um contexto prévio de reflexão e deliberação onde é preciso o uso da memória (Gr.: mermairō, mermerizō, merimnaō, merimna). Esses termos são traduzidos para o Latim como: memor, memoria. Assim, martys, aponta alguém que tem conhecimento de algo de memória e que pode, então, falar e ponderar a respeito dessa lembrança. Os derivados de martyr são: o verbo martyrein, que denota estado ou atividade habitual de ser uma testemunha, vir a tornar-se testemunha, dar testemunho de algo; o substantivo martyria, mais abstrato, significando o(a) portador(a) de testemunho; e o substantivo martyrion, mais concreto, como a prova ou evidência para o testemunho dado (STRATHMAN, 1967, p. 474-475).

Desde os tempos homéricos, os gregos usaram a palavra martyria no sentido de alguém fazer uma afirmação pública da participação e/ou observação de algum evento na qualidade de testemunha (martys):

Seu conteúdo léxico pode ser mais exatamente definido como lembrança refletida e interrogativa, "relembrar", isto é, "chamar para a consciência" alguma coisa que alguém experimentou que não pode ser negligenciada ou esquecida, e que agora, neste sentido, é trazida à atenção de outras pessoas, a fim de transmitir a estas, por meio de declarações

INTERAÇÕES, Belo Horizonte, Brasil, v. 14, n. 25, p. 145-168, jan./jun. 2019

ISSN 1983-2478 
apropriadas, o conteúdo desta experiência: aquilo que foi experimentado ficará sendo evidente mediante o testemunho. (COENEN, 1983, p. 610).

Um uso claro, temos em Gálatas 4, 8-16. Perante a inconstância dos gálatas, Paulo declara: "Pois eu vos presto este testemunho (martyrō): se pudésseis, teríeis arrancado os vossos olhos para dá-los a mim" $(\mathrm{Gl} 4,15)$. Paulo recorre à memória da primeira estadia entre os gálatas, para leva-los à reflexão sobre a indiferença presente para com o apóstolo, e para movê-los a uma retomada do antigo interesse por Paulo.

O testemunho também é a declaração ou fala de uma testemunha, alguém que viu, porque esteve presente (Latim: testis), a um fato ou acontecimento. Ou, alguém que, presente em uma conversa entre duas pessoas, pode fazer um juízo sobre o que estão dizendo e oferecer sua opinião a respeito (Latim: terstis). Em qualquer dos usos, a testemunha e o testemunho têm nítida conotação visual, ocular, representado no uso assemelhado da palavra histor: aquele que sabe porque viu (BENVENISTE, 1995, p. 122; 175). Assim, o testemunho é a fala da testemunha acerca de um acontecimento ao qual esteve presente, vendo-o com os próprios olhos, podendo falar sobre ele porque sabe do que está falando: "Eu sei do que estou falando, porque estive lá, e vi com meus próprios olhos!".

Também é testemunha alguém que, passando por um evento, sobreviveu a ele, e cuja existência continua mesmo depois de um longo tempo percorrido (Latim: superstes). Não existindo mais o evento, isto é, não sendo mais acessível no tempo, é a única testemunha dele, e o seu testemunho falado, vez após vez, é a única maneira de saber sobre ele (BENVENISTE, 1995, p. 278). O testemunho substitui o acontecimento, na sua ausência e na impossibilidade da sua repetição. $O$ ocorrido ressurge e cresce a partir do ato de fala da testemunha, que se torna uma espécie de autor, de onde vem a autoridade (autorictas) mesma do testemunho: sua validade e poder de, a partir da palavra, criar alguma coisa nova no mundo (BENVENISTE, 1995, p. 151-152). Desse modo, a testemunha não apenas fala de um acontecimento no qual esteve presente, ela também o recria, especialmente quando o acesso ao ocorrido não é mais possível. Seu testemunho serve de evidência: "Eu estive lá, e posso dizer como as coisas, realmente, aconteceram!".

O testemunho pode ser estendido para além da sentença declaratória ou assertiva, para abranger um caráter narrativo, como o relato acerca de algo, ao invés da simples e direta informação sobre ele; um caráter documental, como documentos, monumentos, acontecimentos passados ou presentes, e outros assemelhados, que são a matéria básica de 
historiadores, jornalistas, etc.; um caráter institucional, como marcas, placas, e outros assemelhados que orientam sobre a conduta em determinada situação (MEDEIROS, 2015, p. 14). Ainda, podemos falar do uso amplo do testemunho, onde alguém está "dizendo algo em um aparente esforço de transmitir (corretamente) informação para outro alguém” (AUDI, 2003, p. 132).

O testemunho carece de ser transmitido, veiculando um conhecimento ou informação a alguém que o ouve, estimulado pelo interesse e capaz de julgar sua importância e necessidade. Esse conhecimento é “aquele que alguém, razoavelmente e diretamente, forma em resposta ao que alguém, razoavelmente toma como testemunho, e que é, essencialmente, causado e sustentado pelo testemunho" (PRITCHARD, 2004, p. 326). São as relações pessoais, individuais e sociais, entre quem fala o testemunho e quem o ouve, que constituem as condições para a transmissão do testemunho e, então, de conhecimento. Logo, o testemunho é um projeto hermenêutico, como autorreflexão de um sujeito, a partir da consciência de si, de uma experiência proporcionada pelo mundo exterior. O testemunho é a transmissão dessa experiência, quando o sujeito penetra o espaço público da intersubjetividade, na qual outros sujeitos, igualmente reflexivos, partilham a experiência comum. Contudo, a cada sujeito corresponde uma consciência, que oferecerá uma perspectiva diferente, que deve ser trabalhada através do diálogo, até que se alcance uma visão comum representada em um testemunho comum a todos. O testemunho jamais é uma coisa acabada, e a sua justificativa e verificabilidade está em constante reelaboração uma vez que os sujeitos epistêmicos também estão em contínuo reposicionamento perante a realidade que os envolve e os testemunhos que trocam entre si. $\mathrm{O}$ testemunho precisa ser dado em um contexto amplo de relacionamentos humanos, onde ele é requisitado, aceito e legitimado.

Assim, o testemunho é um fenômeno cultural e histórico, correspondendo às condições culturais e sociais que permitem seu acontecimento. As condições culturais para o testemunho, temos na oralidade. As condições sociais para o testemunho, temos nas relações sociais, onde as pessoas podem falar a partir de si mesmas, refletindo sobre suas experiências de vida, favorecendo a multiplicidade de pontos de vista sobre um certo acontecimento. 


\section{SOBRE OS TESTEMUNHOS E AS TESTEMUNHAS NO EVANGELHO DE MARCOS}

Uma vez que o evangelho composto por Marcos é uma transcrição de testemunhos, deve ser tratado como uma literatura que representa esse fenômeno cultural e social de meados do século I, situado no contexto mais amplo do Antigo (Primeiro) e Novo (Segundo) Testamentos (Pactos). No Antigo Testamento, o testemunho é uma asserção acerca de Deus que deve ser acolhida por quem ouve, ainda que esteja aberta ao exame comparativo com outros testemunhos em busca do melhor conhecimento sobre a verdade do que é dito sobre ele. No entendimento de Brueggemann (2014):

O papel do testemunho é advogar uma apresentação da verdade e uma versão da realidade que está em disputa com outras apresentações e versões. As testemunhas de Javé no Antigo Testamento advogam uma verdade e uma realidade na qual Javé se situa como o Personagem principal e proeminente (BRUEGGEMANN, 2014, p. xv).

O testemunho é o modo como Israel constrói seu discurso sobre Deus a fim de veicular seu conhecimento acerca dele. Apesar da variedade de asserções, há um testemunho básico, ou característico, no discurso de Israel sobre Deus, que são as afirmações centrais constituídas por sentenças completas:

A sentença completa do testemunho, que caracteristicamente se torna revelação em Israel, se organiza em torno de um verbo ativo que manifesta uma ação transformadora, invasiva ou inversora (de Javé) [...] que cria uma nova situação ou uma circunstância transformada que não existia anteriormente. [...] Assim, a reivindicação característica do testemunho de Israel é que Javé é um agente ativo, sujeito de um verbo ativo; dessa forma, o testemunho afirma que Javé, o Deus de Israel, tem atuado de modos decisivos e transformadores (BRUEGGEMANN, 2014, p. 183-184).

O testemunho de Israel sobre IHWH é que ele atua para modificar positivamente as situações de vida do povo israelita, individual e coletivamente, sendo este o objeto da sua atuação. Este testemunho é dado no ambiente das nações e da criação, pois menciona acontecimentos comuns a todos, para os quais Israel, como testemunha, explica o agir em seu favor. Naturalmente, esse objeto do agir pode ser ampliado para todas as nações e toda a criação.

A sentença testemunhal israelita é substanciada no discurso da tōdah, ou ação de graças, no qual Israel anuncia o que IHWH fez por ele, confessando seu livramento ou 
salvação, "por meio da qual Israel expressa alegria, assombro e gratidão por um dom concedido ou uma ação realizada, dom ou ação que mudou decisivamente as circunstâncias de Israel” (BRUEGGEMANN, 2014, p. 189). À confissão da tōdah junta-se a declaração da justiça de IHWH: “[...] a pronta capacidade de Javé de estar presente em situações de tribulações, de intervir poderosa e decisivamente visando a reabilitação, restauração e bemestar.” (BRUEGGEMANN, 2014, p. 192-193).

O testemunho israelita é uma sentença declarativa que resume uma ação de IHWH favorável, livradora e salvadora de Israel. Ela pressupõe, portanto, um acontecimento que é relembrado vez após vez no testemunho. Este retorna continuamente ao acontecimento cuja narrativa é uma forma expandida do testemunho, servindo de descrição para ele, possibilitando falar de testemunhos narrativos ou de narrativas testemunhais. Portanto, o testemunho é um convite a rememorar o ato salvador de IHWH em uma celebração cúltica marcada pela aclamação, alegria e júbilo:

Cantai ao Senhor um cântico novo, porque ele tem feito maravilhas; a sua destra e o seu braço santo lhe alcançaram a vitória. O Senhor fez notória a sua salvação; manifestou a sua justiça perante os olhos das nações. Lembrou-se da sua misericórdia e da sua fidelidade para com a casa de Israel; todos os confins da terra viram a salvação do nosso Deus. Celebrai com júbilo ao Senhor, todos os confins da terra; aclamai, regozijai-vos e cantai louvores (Salmo 98, 1-4).

O evangelho escrito por Marcos ecoa essa característica fundamental do testemunho central de Israel. A opção marcana não é compor o testemunho a partir de afirmações assertivas sobre Jesus, resumindo as suas ações, porém usando a forma expandida da narrativa de seus atos livradores e salvadores. No testemunho marcano, os atos de Jesus substituem os de IHWH, como sujeito, enquanto os beneficiados substituem a Israel, como objeto. A intenção é apresentar a Jesus agindo de tal modo transformador que não haveria outro comparável a ele, tal como pode ser dito dos atos de IHWH, por Israel. Ao fim de cada um desses relatos caberia a fórmula assertiva: Deus tem feito maravilhas, fez notória a sua salvação, manifestou a sua justiça. Algo próximo disso, temos na declaração da multidão após Jesus curar o paralítico de Cafarnaum: "a ponto de se admirarem todos e darem glória à Deus, dizendo: Jamais vimos coisa assim!” (Mc 2, 12); e na declaração da multidão após ver Jesus curar um surdo-mudo: "Maravilhavam-se sobremaneira, dizendo: Tudo Ele tem feito esplendidamente bem; não somente faz ouvir os surdos, como falar os mudos" (Mc 7, 37). Isso explica a escolha de dez atos de cura e três de exorcismos cujos testemunhos são 
recolhidos no texto marcano: a sogra de Pedro (Mc 1, 29-31); o leproso (Mc 1, 40-45); o paralítico (Mc 2, 1-12); o homem de mão seca (Mc 3, 1-6); a filha de Jairo (Mc 5, 21-24; 3543); a mulher com hemorragia (Mc 5, 25-34); a siro-fenícia (Mc 7, 24-30); o surdo-mudo (Mc 7, 31-37); o cego de Betsaida (Mc 8, 22-26); o cego Bartimeu (Mc 10, 46-52). E dos três testemunhos de exorcismo: homem da sinagoga de Cafarnaum (Mc 1, 32-34); o geraseno (Mc 5, 1-20); o menino epilético (Mc 9, 14-29). Por eles, Jesus recria em meio ao caos, faz promessas em meio ao desespero, liberta em meio à opressão, ordena em meio à confusão e guia em meio ao abandono, tal como IHWH havia operado, no passado, para com Israel (BRUEGGEMANN, 2014, p. 292-295).

No Novo Testamento, Pedro e os Onze, mais Paulo, são testemunhas/martyres: aqueles que viram e ouviram a Jesus de Nazaré, terreno, mas especialmente ressurreto, elaboraram e guardaram para si essa memória e foram encarregados de dar testemunho dela pelo próprio Cristo ressurreto. Dunn os chama “custodiadores da tradição", especificamente, Pedro, João, Tiago e Paulo (DUNN, 2003, p. 180). A designação martys funciona especificamente para denotar esse papel oficial e autorizado, a eles reservado (Lc 1, 2; Lc 24, 44-48; At 1, 6-8; At 2; At 2,22-32; At 3, 15; At 5, 32; At 10, 39-43; At 13, 31; At 22, 15; At 26, 16; Jo 1, 1-2). A importância da formalização ainda é mais forte quando seu testemunho é considerado sob o pano-de-fundo escatológico que abrange a proclamação do Evangelho. A fidelidade do seu testemunho seria julgada na corte celestial de Jesus Cristo (Mc 8, 38). E, as pessoas seriam julgadas, na mesma corte, com base na aceitação ou rejeição da veracidade do testemunho apostólico (TRITES, 1968, p. 20; 25).

No evangelho marcano, o testemunho apostólico acusa a rejeição ao arrependimento e fé no Ungido Jesus de Nazaré, que traz o tempo da oportunidade na oferta do Reinado de Deus. Ele está inteiramente associado à missão de Jesus: “foi Jesus para a Galileia, pregando o evangelho de Deus" (Mc 1, 14). Tempos depois, ele apontou (epoiēsin) doze dos discípulos "para estarem com ele e para os enviar a pregar (apostelle ... kēryssein) e a exercer a autoridade de expelir (eksousian ekballein) demônios" (Mc 3, 14-15). Jesus passou a percorrer as aldeias dos arredores, chamou os doze até ele (proskaleitai), enviou-os (apostellein) dois a dois, certamente "a pregar" e testemunhar, conforme Marcos 3, 15, e dando-lhes autoridade (eksousian) sobre os espíritos imundos (Mc 6, 7). O ato de constituição é o mesmo de Marcos 3, 14-15, com a diferença de que, agora, eles estão formalmente em missão, doravante serve-lhes a designação de apóstolos (Mc 6, 30). Caberá 
a eles o testemunho da incredulidade e recusa dos impenitentes em ouvir a pregação, perante o juízo que se aproxima, para a sua condenação (Mc 6, 11).

Situação análoga temos na missão dos discípulos antes do Fim (Mc 13, 9-11). Muda o cenário do testemunho: tribunais e sinagogas, governadores e reis de todas nações, onde o evangelho será pregado (kēryxthēnai, Mc 13, 9-10). Por essa atividade, acontecerão ocasiões em que eles serão conduzidos e entregues (agōsin ... paradidontes), e deverão falar de forma mais improvisada e pontual, típica do interrogatório em uma corte, o que for dado a dizer pelo Espírito Santo (lalountes alla to pneuma to hagion, Mc 13, 11). A rejeição e os sofrimentos impingidos serão, por sua vez, o testemunho, que será dado pelos apóstolos, desfavoravelmente contra seus interrogadores, como evidência da sua incredulidade e rejeição do Ungido (Mc 13, 9). Eles não devem se envergonhar (epaischynthē) dele, e de suas palavras, perante uma geração adúltera e pecadora, pois o Filho do Homem também se envergonhará deles, quando vier na glória de seu Pai com os santos anjos (Mc 8, 38). De acordo com o contexto imediato (Mc 8, 34-37), a recusa ao testemunho, tomada como vergonha, está associada ao medo da morte: perder a vida ou a alma (apolesei tēn psychēn). A geração adúltera e pecadora é uma corte judicial que poderia receber ou recusar o testemunho dos discípulos. Por medo de morrer, os discípulos recusariam o testemunho favorável ao Ungido. A consequência é grave: o Filho do Homem, na sua vinda gloriosa, recusaria seu testemunho favorável aos discípulos, perante a corte celestial: o Pai e os anjos santos, com as consequências disso perante o juízo final: perder a alma ou a vida. Qual tribunal deveria ser mais temido? Portanto, levantar a cruz sobre si mesmo (aratō ton stauron, Mc 8, 34), tal como Jesus já o fez, era a condição fundamental para dar o testemunho.

Afora o testemunho apostólico, as congregações seguidoras de Jesus de Nazaré cuidaram de recolher os testemunhos daqueles que viram e ouviram o que Jesus fez e disse, e de recontá-los a outros tantos que estivessem dispostos a ouvi-los. Isto assegurava a continuidade com as obras e ensino de Jesus (didaskalos) e preservava o traço característico deles como seus aprendizes (mathètai). Esse processo foi conduzido pelos mestres disponibilizados e sustentados nas congregações (DUNN, 2003, p. 174-177). Esse procedimento foi nutrido por dois motivos que foram o testemunho e a memória, indicando: “[...] um forte senso dentro do Cristianismo do primeiro século da necessidade de assegurar a continuidade da tradição desde as primeiras testemunhas até os subsequentes discípulos 
e de uma vida vivida consistentemente com aquela tradição.” (DUNN, 2003, p. 178, tradução nossa).

No Evangelho segundo Marcos, os testemunhos não apostólicos estão localizados entre os capítulos 1 a 10. Eles não estão vinculados ao testemunho apostólico em ambiente formalmente judicial. Tanto em seus casos episódicos, quanto nos resumos gerais desses casos, eles funcionam como testemunhos informais do Ungido e sua missão. Os testemunhos são pessoais e privados, circunstanciais e oferecidos, espontaneamente, ao juízo de uma audiência pública. Claramente, existem determinados parâmetros para esse procedimento segundo aprendemos com Kelber (1991), Bailey (1995) e Dunn (2003; 2013), em seus estudos sobre a etapa da transmissão oral.

Para Kelber (1991), nos testemunhos de cura do Evangelho permanece a estrutura de um relato oral, sendo seus traços típicos: a uniformização da estrutura e a variedade de experiências de cura; o enredo dramático ao redor de duas personagens: o doente e o curador, e de dois elementos: doença e cura; a ênfase no acontecimento sobrenatural em detrimento da ação ordinária; a redução da ação dos personagens a uma única atitude: súplica e cura. Típico da transmissão oral é a presença da mesma organização uniforme que permite grande variação na execução narrativa, onde partes são ampliadas ou reduzidas, e até modificadas, dependendo do público e do improviso necessário. Existe uma sintaxe oral no texto marcano, onde as narrativas, reunidas entre os capítulos 1 a 10, são curtas e constituem a espinha dorsal do Evangelho. De modo típico a um contador de histórias, esta consiste em:

(a) escolhas lexicais: sentenças iniciadas por kai egeneto ou kai ginetai; ou pelos advérbios euthys e kai euthys ou palin e kai palin; e sentenças paratáxicas com kai;

(b) escolhas retóricas: tríades, duplos, uso do passivo, terceira pessoa do plural, presente histórico com legein e erchesthai, discurso direto, passagem do discurso indireto para o direto, acumulação, repetição de palavras, cláusulas, temas;

(c) escolhas narrativas: preferência da ação sobre a palavra; descrição dos personagens em ação, de modo que as narrativas é que dão forma aos personagens. Em resumo, tudo indica que não havia uma estratégia narrativa estranha e prévia, imposta desde fora, na composição da obra marcana, mas que Editor-Autor recolheu e manteve os relatos orais do jeito que os recebeu, deixando que eles definissem a forma de seu texto (KELBER, 1991, p. 108-117). 
De acordo com Bailey (1995), observamos, no texto marcano, dois modelos de transmissão oral. Os episódios discursivos ou de debates sugerem uma transmissão coletiva, formal e controlada, enquanto que os episódios das narrativas individuais apontam para uma transmissão individual, informal e flexivelmente controlada. A transmissão oral retém o controle do conteúdo: o enredo da história não pode ser mudado, mas os detalhes são mais livres e mais sujeitos a variações, adições e subtrações. A hipótese baileyana é que até o levante da guerra judaico-romana, nos anos de 70, as congregações cristãs cultivaram uma transmissão oral controlada informal dos testemunhos sobre Jesus de Nazaré, para elas, o Ungido Filho de Deus. Com a guerra, boa parte das aldeias onde estavam as congregações foi destruída, obrigando seus habitantes, inclusive os cristãos, a se deslocarem. Onde se assentaram, de novo, o processo de transmissão oral foi continuado por seus membros que ainda retinham na memória os testemunhos originais. E, assim, o processo foi continuado até a transcrição e edição do texto marcano, e, mesmo, após a sua publicação (BAILEY, 1995, p. $7-8 ; 11-13)$.

Para Dunn (2003), as variações nas histórias de curas entre os Evangelhos sinóticos não indicam uma dependência literária, tal como foi proposto desde a Crítica das Formas. Antes, apontam para um procedimento oral onde a mesma história era recontada diversas vezes retendo, porém, seu núcleo central. Isso também elimina a necessidade de uma dependência oral, visto que as histórias poderiam ter sido ouvidas de modo diferente por um e outro evangelista, ou, mesmo, ele poderia ter recontado de modo diferente de acordo com sua intenção e seu público. Assim, os testemunhos circulavam entre as congregações cristãs, e mesmo fora delas, em versões diversas, sendo que uma ou mais de uma delas veio a ser fixada na transcrição e edição final do texto de cada Evangelho. Dunn advoga que as congregações cristãs deram um tratamento específico aos testemunhos recebidos na medida em que interessavam e importavam para a formação de suas identidades, interna e externamente, consequentemente, sua ênfase é antes no processo de tradição oral do que na comunicação oral dos testemunhos e sua presença nela (DUNN, 2003, p. 216-220).

Desse modo, a transmissão oral-aural de testemunhos individuais antecede a etapa de fixação de tradições orais, em uma cadeia de transmissão oral informal, flexível, plástica, e aberta a muitas variações. Examinamos, a seguir, alguns casos exemplares desses testemunhos. 


\subsection{O caso do leproso (Mc 1, 40-45)}

Após a cura, Jesus impõe duas condições ao leproso: não dizer (eipēs) nada a ninguém e mostrar-se ao sacerdote, oferecendo a purificação ordenada na Lei de Moisés (Lv 13, 14$15 ; 45-46 ; \mathrm{Lv} 14,11-19)$. Ao fazê-lo, o leproso teria, necessariamente, que testificar da cura efetuada por Jesus, validando seu ato perante o juízo do sacerdote e do povo. Doravante, o testemunho do leproso foi contínuo, direto, desafetado e desimpedido. Ele relatou, divulgou, espalhou rumores (diafémizein ton logon), falou, como testemunha, de sua experiência de cura por Jesus. Ele tornou público (fanerōs), manifesto, aberto, nítido e claro, o que era um acontecimento particular e privado até agora. Por seu testemunho, Jesus se tornou de tal modo conhecido que não mais podia entrar abertamente em nenhuma cidade. Ele passou a andar em lugares vazios (erēmois), sem pessoas. Todavia, até nesses lugares as pessoas passaram a procurá-lo.

\section{2 O caso dos parentes de Jesus e dos escribas de Jerusalém (Mc 3, 21-22)}

Caso típico de testemunho desfavorável a Jesus foi aquele dado por seus parentes ou próximos dele. O motivo aparente é o novo afluxo da multidão à casa de Jesus, em Cafarnaum. Isso já ocorrera anteriormente (Mc 2, 1-2). Algum tempo havia decorrido entre o início de sua missão (Mc 1, 38) e o seu retorno para casa (Mc 3, 20). Nesse período, o fluxo de pessoas somente aumentou e, segundo o comentário do Narrador, naquele dia eles nem podiam comer pão. As pessoas, repetidamente, entravam na casa para conviver com Jesus, e a enchiam, dando a impressão de uma grande aglomeração de pessoas todo o tempo (synerchetai palin, Mc 3, 20). Essa situação chegou até os ouvidos dos parentes de Jesus que, surpresos, decidiram ir até a casa dele, para subjugá-lo, agarrá-lo e levá-lo à força, de volta para a casa da família (kratēsai auton, Mc 3, 21). Entre si, declaravam que ele estava em um estado mental fora da normalidade (eksestē), de modo a justificar a sua ação.

O outro testemunho desfavorável foi dado pelos escribas que desceram de Jerusalém. Uma prática corrente de Jesus, nesse período, foi a de expelir demônios (Mc 1, 25-26; 34; 39; Mc 3, 11). Como na oportunidade anterior (Mc 2, 1-2; Mc 6), escribas estavam em sua casa, observando sua atividade e comportamento. Sua declaração está apoiada na atividade geral de Jesus, e não somente em algo que o tenham visto fazer naquele dia. Na vez anterior, eles negaram a Jesus a autoridade para perdoar pecados (eksousian, Mc 2, 10). Nesta, 
declararam que a autoridade de Jesus para expelir demônios (ekballei ta daimonia) vinha do fato de Belzebu, o maioral dos demônios, (archonti tōn daimoniōn) possuí-lo (Beelzeboul echei, Mc 3, 22). De fato, eles testemunhavam que Jesus estava possesso de um espírito imundo (pneuma akatharton echei, Mc 3, 30).

\subsection{O caso do possesso de Gerasa (Mc 5, 1-20)}

A cura do possesso de Gerasa é um caso paradigmático para o exame do testemunho. Temos uma situação de total alienação e decrepitude de um homem causado pela ação de um ou muitos espíritos imundos, de conhecimento geral na região. Há uma situação conflitiva entre os espíritos imundos e Jesus, na qual Jesus exerce juízo sobre eles, expulsando-os da sua presença, o que resulta, por sua vez, na libertação do homem. Uma manifestação física, também metafórica, é associada a esse juízo na morte dos porcos afogados no mar. Os cuidadores dos porcos presenciaram os acontecimentos e correram para a cidade e, passando pelos campos, anunciaram o seu testemunho: um anúncio informal aos que encontravam pelo caminho, e um relatório formal que eram obrigados a fazer aos, provavelmente, proprietários dos porcos (apēngeilan, Mc 5, 14). Como de praxe, estes foram até o lugar onde o evento se deu para assegurar do testemunho dado, e muitos curiosos foram com eles. Constataram que o testemunho estava correto, pois viram o endemoninhado "assentado, vestido, em perfeito juízo" (Mc 5, 15). Ainda, obtiveram um novo testemunho através do relato completamente detalhado, do começo ao fim, daqueles que viram, como testemunhas, os fatos ocorridos (diēgēsanto autois hoi idontes pōs egeneto, Mc 5, 16). Com base nos dois testemunhos, e no que eles mesmos viram, decidiram pela saída de Jesus da sua região. O homem libertado insinuou acompanhar a Jesus, mas ele recusou, dizendo-lhe que voltasse para aqueles de sua casa e desse seu testemunho, um relatório detalhado "de tudo o que o Senhor te fez e como teve compaixão de ti" (apangeilon, Mc 5, 19). Foi exatamente o que ele fez, anunciando (kēryssein, Mc 5,20), em toda a Decápolis, "tudo o que Jesus lhe fizera”.

\subsection{O caso da mulher com hemorragia (Mc 5, 25-34)}

A cura da mulher com hemorragia é outro caso modelar de testemunho. Seu quadro é trágico, tanto do ponto de vista da saúde, pois sofria do mal há doze anos, piorando cada 
vez mais; quanto do ponto de vista social, pois gastara todos os recursos com os médicos. Sua procura por Jesus aconteceu porque ela ouviu acerca dele (akousasa peri tou Iēsou, Mc 5, 27), certamente os muitos testemunhos sobre os atos de Jesus que chegaram até ela, tema recorrente na decisão das pessoas de procurar a Jesus. Ela não quis ou não pôde ir, abertamente, até Jesus e decidiu tocá-lo ocultamente. Logo, percebeu que a hemorragia havia cessado, e que seu corpo já não anunciava o mesmo mal (mastigos, Mc 5, 29), quando ela passou a saber (egnō) que não tinha mais a doença. A reação de Jesus forçou a mulher a manifestar-se. Esta, responsivamente, deu o testemunho conforme o que viu em seu próprio corpo: "declarou-lhe toda a verdade" (eipen autō pasan tēn alētheian, Mc 5, 33). A declaração da verdade inteira significava dizer um relato, ponto a ponto, do começo ao fim, de sua vida, de seus motivos para ir até Jesus, da razão da sua ocultação, e do conhecimento, acima de qualquer dúvida, da experiência que acabara de viver. A despedida de Jesus para que ela vá em paz (hypage eis eirēnēn, Mc 5, 34), agora livre do mal, implicava, necessariamente, o compartilhamento do testemunho com os seus, e demais conhecidos, do lugar de onde ela veio e para onde ela voltou.

\subsection{O caso da filha de Jairo (Mc 5, 35-43)}

Mais um caso exemplar temos no testemunho de cura ou ressurreição da filha de um dos principais da sinagoga de Cafarnaum, chamado Jairo. Nela, os observadores do ato de Jesus são o pai e a mãe da criança, e os discípulos: Pedro, Tiago e João. Perante o reviver da criança, todos foram tomados por um êxtase, uma perda do domínio habitual dos sentidos e da sensação de realidade. Essa percepção foi forte o bastante para ser descrita como grande, como se tivessem ficado totalmente fora de si (ekstasei megalē, Mc 5, 42). A orientação de Jesus foi uma advertência para que retomassem o autocontrole, senão, nada de razoável poderia ser dito acerca do que eles haviam acabado de presenciar, invalidando o testemunho. A sua total interdição, para que ninguém tivesse conhecimento do acontecido, caso viessem a ser interrogados a respeito (diesteilato, Mc 5, 43), se deveu à dificuldade de explicação. Posteriormente, esse testemunho foi dado, após não mais existirem as condições de segredo partilhado pelo grupo. 


\subsection{Os casos da aldeia de Nazaré, da corte do rei Herodes e da gente comum (Mc 6, 1-3; 14-16; Mc 8, 27-29)}

Reuni quatro casos emblemáticos, idênticos no testemunho. Neles, temos os habitantes da aldeia de Nazaré, a corte do rei Herodes, a gente comum e os Doze oferecendo seu testemunho ou dizendo, declarando (légontes) algo sobre Jesus. Eles o fazem a partir de sua perspectiva, isto é, sua experiência e conhecimento comum da realidade em contraste com o que ouvem e veem de Jesus. Da recepção do novo testemunho surge a necessidade de adequar ou modificar o testemunho existente. Trata-se de um típico testemunho de grupo, visto que os indivíduos conversam entre si a fim de concordar em um único testemunho dado por todos.

Na aldeia de Nazaré (Mc 6, 1-3), os seus moradores já possuíam um testemunho formado sobre Jesus, adquirido dos anos de convivência com ele e sua família. Porém, viram na performance de Jesus, na sinagoga, outro testemunho: a sabedoria (sofia) no seu ensinamento, e os poderes (dynamai) que operavam nele na realização de curas. A recepção desse testemunho os deixou sem saber o que dizer, totalmente dominados pelo impacto da experiência (ecseplēssonto, Mc 6, 2). A conjuntura os levou a uma situação difícil: ou reavaliavam o que já sabiam sobre Jesus com base no novo testemunho recebido, ou se apoiavam no testemunho anteriormente elaborado. O escândalo mostra um estado confuso, de ressentimento, preconceito e repugnância dirigido contra a pessoa de Jesus (eskandalizonto, Mc 6, 3).

Na corte do rei Herodes (Mc 6, 14-16), a fama de Jesus já havia chegado, o que indica uma atividade contínua e abundante de testemunhos de seus atos, despertando a atenção para os poderes com os quais ele operava: "nele operam forças miraculosas" (energousin hai dynameis en autō, Mc 6, 14). Os receptores desses testemunhos os associaram com algum testemunho prévio: a atividade dos profetas, desde o mais imediato, João Batista, até o mais distante, Elias ou outro qualquer assemelhado. Herodes é mais incisivo, até pelo curioso autotestemunho em que ele fala de si mesmo como o autor da ordem para a decapitação de João: "É João... que ressurgiu" (Mc 6, 16). O testemunho sobre os profetas é que eram pessoas de atuação extraordinária, e, se Jesus agia de modo extraordinário, ele também era um profeta. Nesse caso, sendo comparado pelo testemunho dado sobre outros.

O testemunho que chegou até a corte de Herodes era dado pela gente comum (Mc 8, 27-28). Eles diziam algo sobre Jesus que mostrava quem ele era (tína me legousin hoi 
anthrōpoi einai? Mc 8, 27). Nele, se misturavam a perspectiva de massas junto com a associação com testemunhos coletivos anteriores: os profetas, desde João Batista, Elias ou algum outro.

\subsection{O caso da declaração de Pedro (Mc 8, 29-38)}

A confissão ou declaração de Pedro é mais um caso paradigmático de testemunho. Ele funciona nas mesmas circunstâncias dos anteriores: "Vós, quem me dizeis ser?" (Hymeis, de tina me legete einai? Mc 8, 29). A particularidade do testemunho se encontra na composição do grupo e na familiaridade com Jesus. Eles convivem com Jesus e é correto esperar que tenham algo diferente a dizer acerca dele. A declaração de Pedro equivale a um testemunho: Tu és o Ungido”. O verbo (legō) serve a uma multiplicidade de funções da fala, dentre elas, a de declarar algo. Isso significa que, uma vez que se declara alguém, está tornando a pessoa o que ela mesma se deu a conhecer. É uma concordância, um reconhecimento: tu és aquilo que tu tens se mostrado para nós. Nesse caso específico, se trata de declarar a identidade de Jesus como o Ungido porque é isso que eles têm observado ao longo do tempo vivido com ele. Ora, uma declaração assume o modo de uma confissão: concordar com algo dando crédito àquilo que vê. Nesse caso, o testemunho de Pedro é uma confissão na qual ele, e os Doze, admitem que Jesus é o Ungido.

Isso conduz a uma compreensão da testemunha quando ela professa algo a respeito de Jesus. Nesse caso, não há apenas a concordância do falante, mas um envolvimento pessoal caracterizado por uma fé ou certeza pessoal naquilo que está dizendo. Ela fala de dentro de si como que convencida daquilo que está dizendo, e a profissão é a mesma coisa que dizer: eu sei que tu és o Ungido. O elemento fundamental desse testemunho é seu caráter de publicidade: declarar, confessar e professar somente são possíveis como um evento externo, público, aberto. Todavia, é curioso que Jesus proíba que esse testemunho alcance o público amplo sem que antes ele sofra, morra e ressuscite ao terceiro dia (Mc 8, 30-31). Certamente, esse evento público deveria acontecer primeiro como testemunho-eventoevidência do testemunho sobre o Ungido, de modo que fosse corroborado por ele. Isso faz todo o sentido quando, após a reprimenda a Pedro (Mc 8, 32-33), Jesus convida a todos que queiram segui-lo, isto é, dar testemunho dele, a levantar sobre si a cruz (Mc 8, 34) perante uma geração adúltera e pecadora (Mc 8, 38). 


\subsection{O caso do homem que expulsava demônios (Mc 9, 38-39)}

Temos outro caso típico de testemunho no episódio do homem que expulsava demônios usando o nome de Jesus. Neste, percebemos o testemunho como um vai-e-vem, um leva-e-traz, um disse-me-disse. João dá testemunho a Jesus de que ele, e os outros, viram um homem que no nome de Jesus expelia demônios (en tō onomati sou ekballonta daimonia, Mc 9, 38). Eles disseram que proibiram esse homem de continuar a fazê-lo. Jesus responde que não deviam fazer isso, porque a atividade do homem sobre o nome de Jesus (epi tō onomati mou) não é um testemunho desfavorável a Jesus (kakologēsai me, Mc 9, 39). O que temos aqui é uma prova de que o testemunho sobre Jesus havia ultrapassado a presença física de Jesus, representando um juízo sobre ele: falar mal ou bem de Jesus.

\subsection{Os testemunhos de Jesus}

Temos, alastrados pelo texto marcano, uma série de testemunhos atribuídos ao próprio Jesus. Em suas falas, ele diz ora da sua compreensão, ora da sua avaliação, ora de advertências, sobre eventos, grupos e pessoas com os quais convive no decorrer de sua missão. Alguns testemunhos descreviam como Jesus compreendia a recepção das pessoas à sua missão: "Não há profeta sem honra, senão na sua terra, entre os seus parentes e na sua casa" (Mc 6, 4); "Ó geração incrédula, até quando estarei convosco? Até quando vos sofrerei?” (Mc 9, 19). Outros testemunhos avaliavam, favorável ou desfavoravelmente, as atitudes das pessoas: "Quão dificilmente entrarão no reino de Deus os que têm riquezas" (Mc 10, 23); "Sabeis que os que são considerados governadores dos povos têm-nos sob seu domínio, e sobre eles os seus maiorais exercem autoridade" (Mc 10, 42); "Não está escrito: A minha casa será chamada casa de oração para todas as nações? Vós, porém, a tendes transformado em covil de salteadores" (Mc 11, 17); "Em verdade vos digo que esta viúva pobre depositou no gazofilácio mais do que o fizeram todos os ofertantes. Porque todos eles ofertaram do que lhes sobrava; ela, porém, da sua pobreza deu tudo quanto possuía, todo o seu sustento" (Mc 12, 43-44). Ainda, outros testemunhos acompanhavam as advertências aos discípulos: "Vede, guardai-vos do fermento dos fariseus e do fermento de Herodes" (Mc $8,15)$, posterior a uma discussão com os fariseus; "Guardai-vos dos escribas" (Mc 12, 38), seguindo uma descrição do que eles fazem. 


\subsection{Testemunhos anônimos}

Em três momentos da missão de Jesus, o testemunho anônimo é vinculado a: admiração, perplexidade e uma observação reverente (ethambēthēsan, Mc 1, 27); ficar fora de si perante a surpresa (eksistasthai, Mc 2, 12); entrega por inteiro a um sentimento de assombro e pasmo (ekseplēssonto, Mc 7, 37). Os termos que qualificam as testemunhas, enquanto sujeitos são: os que se depararam com a expulsão do espírito imundo (hapantes, Mc 1, 27); todos os que viram o paralítico andar perante eles (pantōn, pantas, Mc 2, 12); aqueles que viram o surdo-gago ser curado diante deles (Mc 7, 37). A mesma reação é comum a todos os testemunhos: eles reconhecem um novo ensino e uma autoridade extraordinária (didachē kainē kai eksousian, Mc 1, 27); eles afirmam jamais ter visto algo assim antes (houtōs oudepote eidomen, Mc 2, 12); tem feito o bem ou beneficiado a todos (kalōs panta pepoiēken, Mc 7, 37).

\subsection{Testemunhos e a publicização: as notícias sobre Jesus}

No texto marcano, os testemunhos exercem a importante função de tornar público ou dar publicidade a Jesus. Isso pode ser entendido de várias maneiras. Os testemunhos cumprem a função de vulgarizar, no intuito de generalizar e tornar comum a pessoa de Jesus, de modo que quanto mais e mais pessoas partilhem da mesma informação e conhecimento sobre ele, tanto mais popular ele se torna. Os testemunhos visam tornar Jesus acessível, dando livre, desimpedida e franqueada aproximação a ele, estimulando as pessoas a procurá-lo onde quer que ele esteja ou vá. Os testemunhos são dados em toda a parte, mas objetivam uma determinada parcela da população sírio-galilaica, constituindo uma plateia ou público-alvo que ele almeja alcançar, mobilizando-a para procurar e seguir a Jesus.

Desse modo, os testemunhos são o modo de colocar Jesus em contato com determinado povo, mobilizá-lo para que este o procure, e criar uma movimentação pública ao redor da pessoa de Jesus. Em outras palavras, gerar fama, popularidade, notoriedade, criando uma reputação, um nome, uma imagem, digna de crédito para ele. Ao fazer isso, busca afastar sua imagem dos boatos, ruídos, rumores, falatórios e mentiras que possam descaracterizar sua reputação perante a audiência que deve ser alcançada por Jesus. Evidente no caso do testemunho da parentela de Jesus: "Está fora de si” (Mc 3, 21), ou dos 
escribas que desceram de Jerusalém: "Ele está possesso de Belzebu” (Mc 3, 22). Casos típicos de testemunho contrário (BRUEGGEMANN, 2014, p. 531-535).

O evento que dá a partida para a publicização de Jesus é o enfrentamento do espírito imundo que controlava um homem, na sinagoga de Cafarnaum (Mc 1, 21-26). A partir daquele exato momento, vazou, ou espalhou, a notícia de Jesus para a totalidade dos habitantes das redondezas da Galileia (Mc 1, 28). Jesus mesmo assumiu para si a tarefa de ir até outro lugar, onde estavam os grandes povoados do interior, pela Galileia inteira, porque, dizia ele: "para isso eu vim" (eis touto gar eksēlthon, Mc 1, 38-39). Começou a se formar uma abundante multidão ouvinte dos testemunhos das coisas que Jesus fazia (Mc 3, 8). Comumente, a recepção do testemunho era designada pela expressão: "tendo ouvido acerca de Jesus" (akousasa peri tou Iēsou, Mc 5, 27). Enorme multidão, em lugares diferentes, já tinha conhecimento suficiente sobre Jesus para identificá-lo quando o viam (epegnōsan, Mc 6, 33-34; 53-54). Mesmo quando Jesus não queria ser identificado (gnōnai), ele não podia deixar de ser percebido ou escapar à observação (lathein, Mc 7, 24). Nas aldeias de Betfagé e Betânia, próximas a Jerusalém, havia pessoas que conheciam a Jesus e estavam prontas para, a partir de um procedimento previamente combinado, entregar-lhe o jumento para montaria (Mc 11, 1-6).

Os testemunhos sobre Jesus geraram um movimento massivo onde todos perguntavam por ele ou buscavam a ele (pantes zètousin, Mc 1, 37). Onde Jesus ia, uma multidão se ajuntava a ele (synēchthēsan, Mc 2, 2; synerchetai, Mc 3, 20; synagetai, Mc 4, 1; synēchthēe, Mc 5, 21); iam até ele (ērcheto pros auton, Mc 2, 13; Mc 3, 8); corriam juntos até ele (synedramon, Mc 6, 33; prostrechontes, Mc 9, 15); aglomeravam ao redor dele (symporeuontai, Mc 10, 1). O Narrador indica sucessivas idas até Jesus (erchetai pros auton), onde ele estivesse, em variegados cenários. As aproximações são de dois tipos. A primeira na qual a pessoa mesma toma a iniciativa: o leproso (Mc 1, 40); a hemorrágica (Mc 5, 27); a siro-fenícia (Mc 7, 25); o pai do filho possesso (Mc 9, 17); o jovem rico (Mc 10, 17); o cego Bartimeu (Mc 10, 50). A segunda na qual as pessoas são trazidas ou conduzidas por outras até Jesus: o paralítico (Mc 2, 3); os enfermos em leitos (Mc 6, 55-56); o surdo gago (Mc 7, 32); um cego (Mc 8, 22); as crianças (Mc 10, 13).

Esse movimento de testemunhos em massa foi consolidado no testemunho apostólico inicial, se nos atermos aos textos de Atos 2, 22 e Atos 10, 37-40, sendo Pedro o porta-voz dos discípulos. O primeiro testemunho temos no sermão de Pedro, no Pentecostes, aos judeus de todas as nações. Ele começou a apresentação de Jesus, o Nazareno, como um homem 
indicado, evidenciado, mostrado, da parte de Deus, com testemunhos indubitáveis (apodedeigmenon) aos homens israelitas. Esses foram os atos poderosos, os prodígios e os feitos (dynamesi kai terasi kai sēmeiois) que Deus fez através de Jesus no meio deles (en mesō hymōn). Pedro apontou os atos extraordinários de Jesus, em sua missão, como testemunhos da presença de Deus nela. Também como evidência de que Deus tinha acolhido a Jesus como seu Ungido. E, ainda, como as devidas garantias exigidas para dar crédito a Jesus, o Nazareno. Pedro completou seu argumento com um apelo direto aos ouvintes: eles mesmos sabiam que o que ele dizia acerca de Jesus era de conhecimento de todos (katōs autoi oidate). Uma argumentação testemunhal própria ao tribunal na defesa de alguém sob julgamento.

O segundo testemunho temos no sermão de Pedro na casa de Cornélio, a uma família de romanos. Ele começou evocando o conhecimento público da família (hymeis oidate) sobre a palavra-testemunho que foi originada a partir de todos os judeus. Ela começou a ser divulgada a partir da Galileia, pelo batismo de João, acerca de Jesus, que era de Nazaré, ungido por Deus com espírito santo e poder (pneumati hagiō kai dynamei). Pedro segue o seu testemunho dizendo que Jesus atravessou, cruzou ou transpôs o território, fazendo, reconhecidamente, o bem e curando todos os tiranizados sob o domínio do diabo. Esses eram testemunhos de que Deus era com Jesus. Estes são corroborados por Pedro e todos os demais que são as testemunhas (martyres) do que Jesus fez nos lugares mais distantes da terra dos judeus e, também, na capital, Jerusalém, onde ele foi morto no madeiro e foi ressuscitado, por Deus, no terceiro dia. O segundo testemunho petrino deixa claro que os testemunhos são declarações que servem como provas ou evidências perante um juízo que se queira fazer sobre quem foi Jesus de Nazaré, ao mesmo tempo que oferecem razões para dar crédito a ele como o Ungido.

Alguns relatos da narrativa marcana sugerem que, em determinadas ocasiões, Jesus proibiu a divulgação, e, portanto, buscou interditar os testemunhos. A primeira amostra é a cura do leproso (Mc 1, 40-44). Após curá-lo, Jesus fez-lhe uma dura advertência, enquanto o afastava de perto de si, para que não declarasse nada a ninguém (mēdeni mēden eipēs, Mc 1, 44). A ameaça não dá muito certo, visto que ele saiu por toda a parte, falando aberta e publicamente, espalhando a conversa (diafēmizein ton logon). Para Jesus, resultou em uma publicidade que o impediu de "entrar publicamente em qualquer cidade, mas permanecia fora, em lugares ermos" (Mc 1, 45). Temos o caso dos espíritos imundos (Mc 3, 11-12). No começo de sua missão, Jesus enfrentou uma forte oposição demoníaca. Os espíritos 
imundos, por diversas vezes, ao contemplá-lo, testemunhavam ou declaravam sobre ele (legontes) ser: o "Filho de Deus”. Jesus se impunha ou investia contra eles (epetima autois), para que não o fizessem manifestado ou conhecido (faneron poiēsōsin). Outro episódio é o da ressurreição da filha de Jairo (Mc 5, 43). No relato, Jesus somente admitiu que entrassem no quarto da criança seus pais e os discípulos, Pedro, Tiago e João. À luz do acontecido, todos ficaram como que fora de si. Jesus explicou, claramente, que eles não deveriam dizer nada do que testemunharam, colocando uma interdição sobre o testemunho (diesteilato autois). O incidente seguinte é a cura do surdo-gago (Mc 7, 31-35). Após a cura, Jesus também colocou uma interdição sobre o testemunho (diesteilato autois, Mc 7, 36). As testemunhas não deveriam declarar (legōsin) nada a ninguém. O comentário seguinte do Narrador é curioso: quanto mais Jesus insistia em interditar o testemunho, eles, em uma escala incomparavelmente maior, davam testemunho aberta e publicamente (mallon perissoteron ekērysson, Mc 7, 36). Essa nota parece referir ao testemunho local da cura do surdo-gago (Mc 7, 37). Porém, é permitido pensar que ela alude à amplitude geral dos testemunhos e o reconhecimento do Narrador de que eles, simplesmente, não podiam ser contidos, nem mesmo por Jesus.

Em outras duas oportunidades são os testemunhos dos discípulos que são impedidos. A primeira ocasião aconteceu quando do testemunho de Pedro sobre Jesus ser o Ungido (Mc 8, 29). Imediatamente, Jesus se impôs e investiu duramente (epetimēsen autois) contra os Doze, para que a ninguém dessem esse testemunho acerca dele (legōsen peri autou, Mc 8, 30). A segunda vez ocorreu com o grupo mais restrito dos Doze: Pedro, Tiago e João, quando do evento da transfiguração de Jesus (Mc 9, 2-8). Na descida do monte, Jesus põe uma interdição ao testemunho (diesteilato autois), para que eles não contassem com detalhes o que viram, do começo ao fim, a ninguém (eidon diēgēsōntai, Mc 9, 9), até o dia da ressurreição do Filho do Homem dentre os mortos. Os três mantiveram a palavra de Jesus fortemente guardada entre eles (logon ekratēsan, Mc 9, 10).

\section{CONSIDERAÇÕES FINAIS}

Dunn (2003) afirma que:

[...] a tradição de Jesus não deixou de circular só porque ela tinha sido escrita; ouvir a leitura de um Evangelho seria parte de uma transmissão oral/aural, a ser 
recontada em círculos adicionais de oralidade; o texto escrito ainda era fluido, ainda uma tradição viva. (DUNN, 2003, p. 250, tradução nossa).

Isso permite que o Evangelho segundo Marcos ainda seja examinado desde a categoria do testemunho, como uma tradição viva, como o registro de uma performance oral/aural. Esse exame carece de uma metodologia exegética baseada em três critérios. $\mathrm{O}$ primeiro é o da oralidade. A transcrição do testemunho oral para o texto escrito deixou traços ou marcas na composição marcana que podem ser recuperadas a partir da análise da sintaxe e do estilo de oralidade presentes nela, de acordo com Kelber. Esta pode ser complementada com o estudo das circunstâncias geradoras dos testemunhos e, ainda, com o estudo comparativo dos mesmos testemunhos nos Evangelhos de Mateus e Lucas.

O segundo critério é o da narratividade. Os testemunhos devem ser tomados como narrativas de vida, depoimentos ou relatos do encontro com Jesus de Nazaré. Para o seu exame é importante o modelo de análise desenvolvido por Daniel Bertaux (2010), somado aos recursos da Narratologia, com seu interesse concentrado nos seguintes elementos da narração: Narrador, foco narrativo, personagens, e a distinção entre estória (story) e discurso (discourse).

O terceiro critério é o da retoricidade. Os testemunhos dão conta do encontro, direto ou indireto, das testemunhas com a missão de Jesus de Nazaré, resultando em sua publicização e, então, o apelo a crer nele. Isso leva a entender que os testemunhos obtêm sua razão de ser somente nas condições de comunicação entre um falante e seu público ouvinte, como enunciados argumentativos cuja análise é possível com o auxílio da Crítica Retórica (rhetorical analysis).

\section{REFERÊNCIAS}

AUDI, Robert. Epistemology: a contemporary introduction to the theory of knowledge. 2. ed. New York: Routledge, 2003.

AUNE, David E. (Ed.) Greco-Roman Literature and the New Testament: selected forms and genres. Atlanta: Scholars Press, 1988.

BAILEY, Kenneth. Informal Controlled Oral Tradition and the Synoptic Gospels. Themelios. v. 20, n. 2, 1995. Disponível em: https://pt.scribd.com/document/ 353281537/Article-Kenneth-Bailey-Oral-Tradition-Synoptic-Gospels. Acesso em: 31 ago. 2017.

BAUCKHAM, Richard. Jesus e as testemunhas oculares. São Paulo: Paulus, 2011. 
BENVENISTE, Émile. O vocabulário das instituições indo-europeias: poder, Direito, religião. Campinas: Unicamp, v. 2, 1995.

BERTAUX, Daniel. Narrativas de vida: a pesquisa e seus métodos. Natal: EDUFRN; São Paulo: Paulus, 2010.

BÍBLIA SAGRADA. Tradução de João Ferreira de Almeida. Revista e Atualizada no Brasil. 2. Ed. São Paulo: Barueri, 2008.

BRUEGgEMANN, Walter. Teologia do Antigo Testamento: testemunho, disputa e defesa. Santo André: Academia Cristã; São Paulo: Paulus, 2014.

COENEN, Lothar. Martyria. In: COENEN, Lothar; BROWN, Colin (Eds.) O novo dicionário internacional de Teologia do Novo Testamento. São Paulo: Vida Nova, v. 4, 1983, p. 610 .

DUNN, James D. G. Jesus remembered. Grand Rapids: Eerdmans, 2003.

DUNN, James D. G. Jesus em nova perspectiva: o que os estudos sobre o Jesus histórico deixaram para trás. São Paulo: Paulus, 2013.

KELBER, Werner H. Tradition orale et écriture. Paris: DUCERF, 1991.

MEDEIROS, Felipe Castelo Branco. Epistemologia do testemunho: uma avaliação crítica. Brasília, 2015. Dissertação (Mestrado em Filosofia). Faculdade de Filosofia da Universidade de Brasília. Disponível em: http://repositorio.unb.br/bitstream/10482/ 19340/1/2015_FelipeCasteloBrancoMedeiros.pdf. Acesso em: 11 ago. 2019.

PRITCHARD, Duncan. The Epistemology of Testimony. Philosophical issues, v. 14, Epistemology, 2004. Disponível em: https://onlinelibrary.wiley.com/doi/abs/10.1111/ j.1533-6077.2004.00033.x. Acesso em: 11. Ago. 2019.

STRATHMAN, H. Martys, martyrion, martyria. In: KITTEL, Gerhard. Theological dictionary of the New Testament. Grand Rapids: Eerdmans, v. 4, 1967.

TRITES, Allison A. The Idea of Witness in the Synoptic Gospels: Some Juridical Considerations. Themelios, n. 5, 1968. Disponível em: https://biblicalstudies.org.uk/ pdf/ifes/5-3_trites.pdf. Acesso em: 19 out. 2017. 